\title{
Determinasi Kualitas dan Kuantitas Minyak Biji Kapas Berdasarkan Analisis Keragaman Genetik pada 22 Aksesi Plasma Nutfah Kapas
}

\section{(Determination Quality and Quantity of Cotton Seed Oil Based on Analysis of Genetic Diversity in 22 Accession Cotton Germplasm)}

\author{
Luluk Ayu Parida ${ }^{1)^{*}}$, M. Tahir ${ }^{2)}$, Jakty Kusuma ${ }^{2)}$ \\ 1) Program Studi Produksi dan Manajemen Industri Perkebunan, Jurusan Budidaya Tanaman \\ Perkebunan, Politeknik Negeri Lampung dan ${ }^{2)}$ Jurusan Budidaya Tanaman Perkebunan, Politeknik \\ Negeri Lampung. Jl. Soekarno-Hatta No. 10 Rajabasa, Bandar Lampung, Telp (0721) 703995 Fax : \\ (0721) 787309 \\ E-mail:lulukayup@gmail.com
}

\begin{abstract}
Cotton plants belong to the family Malvaceae with the genus Gossypium. The genus Gossypium is very large containing 50 species. Balittas Malang has a collection of cotton germplasm, about 662 accessions consisting of 642 accessions of G. hirsutum, 14 accessions of $G$. barbadense, 3 accessions of G. arboreum, and 3 accessions of G. herbaceum. In addition to its ability as a producer of fiber, its seeds can also be utilized as a source of oil and is a secondary production. The purpose of this study was to measure and estimate the genetic diversity of cotton germplasm based on the character of superior quality and quantity of cotton seed oil from several cotton plant genotypes and determine which cotton plants have good quality and quantity of cotton seed oil which is subsequently used as breeding sources \& national cotton development elders. To achieve this goal, the experiment was conducted with the experimental method Randomized Block Design (RBD) consisting of 2 replications, 22 germplasm accessions as treatment, and 5 samples in each genotype. The observational parameters are the parameters of oil content quality, oil boiling point, oleic content, and linoleic content. Then the cluster analysis shows that there are 3 cluster analysis groups. Extensive genetic diversity will be beneficial in developing better quality and quantity of cottonseed oil, namely in accession of CRISS-665, CRISS-667, and KANESIA-14 which contribute more than accession of other cotton germplasm to the maximum value of quantity and quality parameters cotton seed oil.
\end{abstract}

Keywords: agronomic evaluation, G. barbadense, G. hirsutum, phenotypic data analysis

DOI: http://dx.doi.org/10.25181/jaip.v7i1.1054

Diterima: 11 Maret 2019 / Disetujui: 22 April 2019 / Diterbitkan: 15 Mei 2019

\section{PENDAHULUAN}

Kapas (Gossypium hirsutum L.) merupakan tanaman perdu semusim yang menjadi salah satu andalan sub sektor perkebunan. Serat yang dihasilkannya banyak dimanfaatkan sebagai bahan baku dalam industri tekstil dan produk tekstil (TPT) Indonesia, tetapi kemajuan industri tersebut belum sepenuhnya mendapat dukungan dalam penyediaan bahan baku. Produksi serat kapas dalam negeri hanya berkisar 1.600-2.500 ton (kurang dari 0,5\% kebutuhan nasional). Sebagian besar diperoleh melalui impor. Nilai ini kian merosot tajam, terlihat pada tahun 2008 produksi kapas masih berada di 
level 3.800 ton,pada tahun 2013 turun drastis pada kisaran 2.500an ton yang berarti selama 6 tahun, yaitu sejak 2008 hingga 2013, produksi kapas turun sekitar 33,69\%. Turunnya produksi disebabkan turunnya produktivitas tanaman dan luas areal penanaman. Pada tahun 2008 produktivitas tanaman petani masih pada kisaran 4,5 kuintal per ha, namun pada tahun 2013 produktivitasnya menjadi 3,1 kuintal per ha (Direktorat Jenderal Perkebunan, 2015).

Balai Penelitian Tanaman Tembakau dan Serat (Balittas) Malang memiliki koleksi plasma nutfah kapas yang berjumlah 662 aksesi yang terdiri atas 642 aksesi G. hirsutum, 14 aksesi $G$. barbadense, 3 aksesi G. arboreum, dan 3 aksesi G. herbaceum. Di antara koleksi plasma nutfah tersebut, 15 aksesi merupakan varietas unggul nasional seri Kanesia (Kapas Nasional Indonesia). Selain untuk kemampuannya sebagai penghasil serat, tanaman kapas dapat di manfaatkan pula bijinya sebagai sumber minyak dan merupakan produksi sekunder (Ashokkumar et al., 2008). Minyak biji kapas merupakan sumber minyak nabati terbesar kedua di dunia. Negara penghasil minyak biji kapas adalah Cina (27\%), Amerika (12\%), India (11\%), Negara bekas reruntuhan Uni Soviet (10\%), dan Pakistan (9\%) terhitung sejak tahun 1995 hingga 2003.

Komposisi minyak biji kapas minyak kapas mengandung asam lemak, misalnya asam miristat, asam palmitat, dan asam lemak tidak jenuh. Jenis asam lemak yang dominan adalah asam palmitat, asam oleat, dan asam linoleat, sedangkan golongan asam dengan jumlah relatif kecil adalah asam miristat, asam stearat, asam arachidat, asam palmitoleat, dan asam miristoleat. Minyak kapas mengandung fosfatida, tetapi sesudah mengalami proses netralisasi dan pemucatan, kadar fosfatida akan menurun.

Penelitian-penelitian tentang keragaman genetik tanaman kapas telah dilakukan oleh Saeed et al. (2014), Tyagi et al. (2014, dan Moiana et al. (2015) dengan menggunakan marka SSR. Nuraida (2012) melaporkan bahwa tanaman kapas di Indonesia memiliki keragaman yang luas. Penelitian ini bertujuan untuk mengukur dan mengestimasi keragaman genetik plasma nutfah kapas berdasarkan parameter kualitas dan kuantitas minyak biji kapas yang unggul dari beberapa genotip tanaman kapas, dan menentukan dan menyeleksi tanaman kapas yang memiliki parameter kualitas dan kuantitas minyak biji kapas yang baik, dan nantinya akan digunakan sebagai breeding source \& tetua pengembangan kapas nasional.

\section{METODE PENELITIAN}

Penelitian dilaksanakan pada bulan Maret 2017 sampai dengan Desember 2017 bertempat di Kebun Percobaan Politeknik Negeri Lampung, Laboratorium Analisis Politeknik Negeri Lampung, dan Laboratorium Yogyakarta. Menggunakan Rancangan Acak Kelompok, terdapat 2 ulangan dan masing-masing ulangan terdapat 5 sampel. Aksesi plasma nutfah kapas yang digunakan dalam penelitian ini sebanyak 22 aksesi yang terdiri atas spesies Gossypium hirsutum, G. arboreum, G. barbadense (Tabel 1). Setiap aksesi yang ditanam pada polybag berisi masing-masing (3) benih, 
adapun tanaman yang tidak dapat tumbuh dilakukan penyulaman. Parameter yang diamati adalah parameter kuantitas jumlah biji.boll ${ }^{-1}$ (butir), bobot biji.100 butir $^{-1}$ (gram), dan hasil biji (kg.ha ${ }^{-1}$ ); sedangkan parameter kualitas kadar minyak (\%), titik didih minyak $\left({ }^{\circ} \mathrm{C}\right)$, kandungan oleat $(\%)$, dan kandungan linoleat $(\%)$. Analisis keragaman genetik dan analisis data fenotipik mengacu pada Kusuma et al. (2018).

Tabel 1. Aksesi plasma nutfah tanaman kapas

\begin{tabular}{|c|c|c|c|}
\hline No. & Kode genotipe & Nama genotipe & Spesies \\
\hline 1 & $\mathrm{~A}$ & CRIS-664 & Gossypium hirsutum \\
\hline 2 & B & CRIS-665 & Gossypium hirsutum \\
\hline 3 & $\mathrm{C}$ & CRIS-666 & Gossypium hirsutum \\
\hline 4 & $\mathrm{D}$ & CRIS-667 & Gossypium hirsutum \\
\hline 5 & E & CRIS-668 & Gossypium hirsutum \\
\hline 6 & $\mathrm{~F}$ & CRIS-669 & Gossypium hirsutum \\
\hline 7 & $\mathrm{G}$ & CRIS-670 & Gossypium hirsutum \\
\hline 8 & $\mathrm{H}$ & CRIS-342 & Gossypium hirsutum \\
\hline 9 & I & Marvi-425 & Gossypium arboretum \\
\hline 10 & $\mathrm{~J}$ & FDH-834 & Gossypium arboretum \\
\hline 11 & K & SA-2467 & Gossypium barbadense \\
\hline 12 & $\mathrm{~L}$ & SA-2465 & Gossypium barbadense \\
\hline 13 & M & KANESIA-11 & Gossypium hirsutum \\
\hline 14 & $\mathrm{~N}$ & KANESIA-12 & Gossypium hirsutum \\
\hline 15 & $\mathrm{O}$ & KANESIA-13 & Gossypium hirsutum \\
\hline 16 & $\mathrm{P}$ & KANESIA-14 & Gossypium hirsutum \\
\hline 17 & Q & KANESIA-15 & Gossypium hirsutum \\
\hline 18 & $\mathrm{R}$ & KANESIA-16 & Gossypium hirsutum \\
\hline 19 & $S$ & KANESIA-17 & Gossypium hirsutum \\
\hline 20 & $\mathrm{~T}$ & KANESIA-18 & Gossypium hirsutum \\
\hline 21 & $\mathrm{U}$ & KANESIA-19 & Gossypium hirsutum \\
\hline 22 & V & KANESIA-20 & Gossypium hirsutum \\
\hline
\end{tabular}

\section{HASIL DAN PEMBAHASAN}

Berdasarkan hasil pengamatan yang terangkum pada Tabel 2, dapat diketahui nilai keragaman pada analisis varians yang di amati pada masing-masing parameter kualitas dan kuantitas. Pada parameter kuantitas data jumlah biji/boll menunjukkan nilai tidak bebeda nyata atau tidak ada pengaruh respon yang terjadi didalamnya hal ini karenakan oleh faktor lingkungan tanaman kapas 
tidak mempengaruhi jumlah biji/boll namun, pada paremeter kuantitas bobot biji.100 butir ${ }^{-1}$ (gram) dan hasil biji $\left(\mathrm{kg} g^{-1} \mathrm{~h}^{-1}\right)$ menunjukkan hasil yang berbeda nyata dikarenakan faktor fenotipik yang mempengaruhi seperti unsur p dalam tanah sesuai yang dengan penelitian (Amiroh, 2009) dalam kandungan pupuk fosfo $\mathrm{N}$ serta unsur hara mikro $\mathrm{Fe}, \mathrm{Mn}, \mathrm{Cu}, \mathrm{Zn}, \mathrm{B}$ dan $\mathrm{Mo}$ dapat diserap secara maksimal oleh tanaman kapas sehingga berpengaruh pada percepatan pembesaran buah.

Pembentukan buah kapas sangat dipengaruhi oleh ketersediaan $\mathrm{P}$ dalam tanaman, kapas yang kekurangan $\mathrm{P}$ disamping hara lainnya seperti $\mathrm{K}, \mathrm{Ca}, \mathrm{Mg}, \mathrm{B}$ dan $\mathrm{Zn}$ maka energi yang diperlukan untuk pembentukan buah akan terhambat. Selain itu $\mathrm{P}$ juga berfungsi untuk mengendalikan karbohidrat, jika karbohidrat yang dialirkan terbatas dapat mempengaruhi jumlah dan bobot buah kapas. Apabila produksi kapas mencapai 700 ton kapas berbiji, maka akan menghasilkan 420 ton biji kapas. Jika potensi biji kapas ini dimanfaatkan, maka akan memberi nilai tambah pada kegiatan agribisnis kapas. Khususnya dalam bidang produksi minyak biji kapas nasional.

Tabel 2. Nilai minimum, maximum, rata-rata, koefisien variasi, dan f-hitung 7 karakter pada 22 aksesi tanaman kapas

\begin{tabular}{|c|c|c|c|c|c|c|c|c|}
\hline No. & Parameter & Min & $\operatorname{Max}$ & $\chi$ & $\mathrm{KV}(\%)$ & F-H & $5 \%$ & $1 \%$ \\
\hline \multicolumn{9}{|c|}{ Kuantitas } \\
\hline 1 & Jumlah biji.boll $^{-1}$ (butir) & 10,2 & 27,6 & 20,8 & 0,771 & 0,020 & $\mathrm{~ns}$ & ns \\
\hline 2 & Bobot biji.100 butir ${ }^{-1}(\mathrm{~g})$ & 5 & 13 & 9,0 & 0,477 & 7,195 & $*$ & $* *$ \\
\hline \multirow[t]{2}{*}{3} & Hasil biji $\left(\mathrm{kg} \cdot \mathrm{ha}^{-1}\right)$ & 18,4 & 819,1 & 193,8 & 2,320 & 4,580 & $*$ & $* *$ \\
\hline & \multicolumn{8}{|l|}{ Kualitas } \\
\hline 1 & Kadar minyak (\%) & 8,31 & 25,15 & 13,96 & 0,863 & 0,025 & $\mathrm{~ns}$ & ns \\
\hline 2 & Titik didih minyak $\left({ }^{\circ} \mathrm{C}\right)$ & 62 & 70 & 66,0 & 0,028 & 3,00 & $*$ & $* *$ \\
\hline 3 & Kandungan oleat (\%) & 2,5 & 6,9 & 4,3 & 0,242 & 0,065 & $\mathrm{~ns}$ & ns \\
\hline 4 & Kandungan linoleat (\%) & 2,21 & 5,78 & 3,5 & 0,231 & 0,042 & $\mathrm{~ns}$ & ns \\
\hline Ceter & 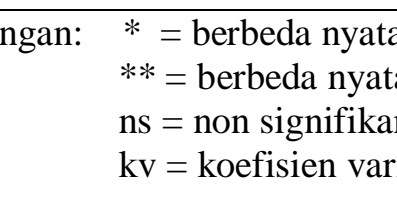 & $\begin{array}{l}\text { araf } \\
\text { taraf } \\
k \text { ber }\end{array}$ & nyata & & & & & \\
\hline
\end{tabular}

Parameter kualitas yaitu kadar minyak, kandungan oleat, dan kandungan linoleat menunjukkan nilai tidak berbeda nyata hal ini di sebabkan karena tidak ada pengaruh lingkungan terhadap parameter tersebut, bahwa komposisi atau kadar asam lemak berbeda-beda, hal ini disebabkan oleh perbedaan sumber iklim, keadaan tempat tumbuh dan pengolahan. Minyak dan 


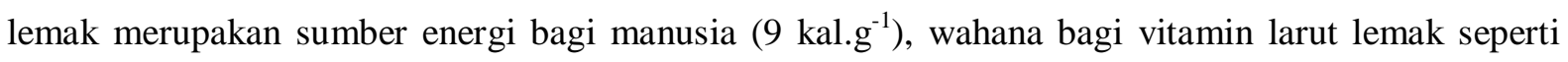
vitamin $\mathrm{A}, \mathrm{D}, \mathrm{E}$, dan $\mathrm{K}$ meningkatkan citarasa dan kelezatan makanan dan memperlambat rasa lapar. Berdasarkan sumber minyak dan lemak dibagi dua yaitu minyak hewani dan nabati. Minyak hewani seperti minyak ikan, sapi dan domba, sedangkan minyak nabati seperti minyak kelapa, minyak sawit, minyak kacang dan minyak zaitun. Dari segi kandungan kimia, minyak disusun oleh asam lemak jenuh, asam lemak tidak jenuh tunggal dan asam lemak tidak jenuh jamak (Chalid et al., 2008).

Pada parameter kualitas yaitu titik didih minyak menunjukkan nilai yang berbeda nyata. Titik didih (boiling point) akan semakin meningkat dengan bertambah panjangnya rantai karbon asam lemak tersebut. Asam lemak tak jenuh tunggal (monounsaturated fatty acid, MUFA) memiliki satu ikatan rantai karbon ganda, contohnya asam oleat (Masyithah et al., 2017).

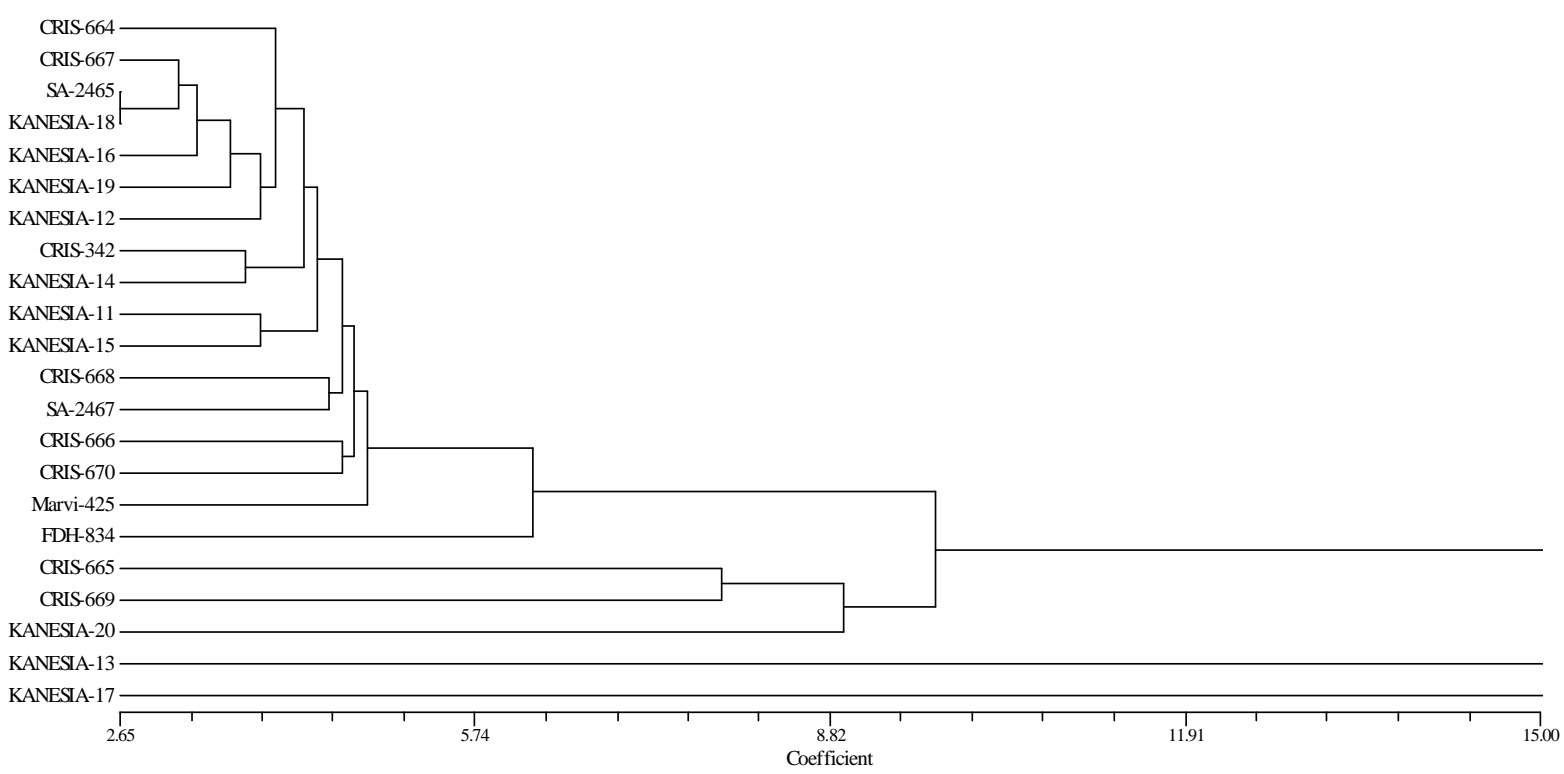

Gambar 1. Analisis kluster pada 22 aksesi plasma nutfah kapas berdasarkan karakter kuantitas dan kualitas fiber kapas

Gambar 1 menunjukkan bahwa grup kluster terbagi menjadi empat kulster yaitu kluster pertama didapatkan data dengan angka minimum menunjukkan 2,65 dan nilai maksimum kurang dari 5,74 . Namun, pada kluster pertama terdapat nilai yang sama pada aksesi plasma nutfah kapas yaitu Gossypium barbadense (SA-2465) dan Gossypium hirsutum (KANESIA-18). Tingkat kemiripan tersebut terjadi di duga akibat level ploidi yang sama. Pada kluster kedua nilai minimum lebih dari yang 2,65, sedangkan untuk nilai maksimum menunjukkan nilai kurang dari 5,74. Pada kluster ketiga didapatkan hasil dengan nilai minimum menunjukkan kurang dari 2,65 dan nilai maksimum yang menunjukkan nilai lebih dari 5,74. Pada grup kluster keempat didapatkan nilai minimum lebih dari 8,82 dengan nilai maksimum 15,00 Nilai kekerabatan seperti ini dinyatakan memiliki tingkat keragaman yang cukup luas antar gen-gen genotip yang berbeda.

Tabel 3. Nama aksesi pada masing-masing grup analisis kluster 


\begin{tabular}{ccccc}
\hline No. & Kluster 1 & Kluster 2 & Kluster 3 & Kluster 4 \\
\hline 1 & CRIS-664 & CRIS-342 & CRIS-668 & CRIS-665 \\
2 & CRIS-667 & KANESIA-14 & SA-2467 & CRIS-669 \\
3 & SA-2465 & KANESIA-11 & CRIS-666 & KANESIA-20 \\
4 & KANESIA-18 & KANESIA-15 & CRIS-670 & KANESIA-13 \\
5 & KANESIA-16 & & MARVI-425 & KANESIA-17 \\
6 & KANESIA-19 & & FDH-834 & \\
7 & KANESIA-12 & & & \\
\hline
\end{tabular}

Tabel 3 menunjukkan bahwa grup kluster terbagi menjadi empat grup kluster yaitu kluster pertama didapatkan data dengan angka minimum menunjukkan 2,65 dan nilai maksimum kurang dari 5,74. Namun, pada kluster pertama terdapat nilai yang sama pada aksesi plasma nutfah kapas yaitu Gossypium barbadense (SA-2465) dan Gossypium hirsutum (KANESIA-18) Tingkat kemiripan tersebut terjadi di duga akibat level ploidi yang sama. Pada kluster kedua nilai minimum lebih dari yang 2,65 sedangkan untuk nilai maksimum menunjukkan nilai kurang dari 5,74. Pada kluster ketiga didapatkan hasil dengan nilai minimum menunjukkan kurang dari 2,65 dan nilai maksimum yang menunjukkan nilai lebih dari 5,74. Pada grup kluster keempat didapatkan nilai minimum lebih dari 8,82 dengan nilai maksimum 15,00 Nilai kekerabatan seperti ini dinyatakan memiliki tingkat keragaman yang cukup luas antar gen-gen genotipe yang berbeda.

Tabel 4. Nilai maksimum kuantitas dan kualitas minyak biji kapas pada masing-masing kluster

\begin{tabular}{|c|c|c|c|c|c|}
\hline No & Parameter & Kluster 1 & Kluster 2 & Kluster 3 & Kluster 4 \\
\hline \multicolumn{6}{|c|}{ Kuantitas } \\
\hline 1 & Jumlah biji.boll $^{-1}$ (butir) & 22,5 & 22,1 & 24,2 & 25,6 \\
\hline 2 & Bobot biji.100 butir ${ }^{-1}$ (gram) & 12 & 11,25 & 9 & 11,25 \\
\hline 3 & Hasil biji $\left(\mathrm{kg} \mathrm{ha}^{-1}\right)$ & 641 & 413 & 222 & 339 \\
\hline \multicolumn{6}{|c|}{ Kualitas } \\
\hline 1 & Kadar minyak (\%) & 16,6 & 13,6 & 16,1 & 19,5 \\
\hline 2 & Titik didih minyak $\left({ }^{\circ} \mathrm{c}\right)$ & 67,4 & 68,2 & 70 & 67 \\
\hline 3 & Kandungan oleat (\%) & 5,4 & 5,4 & 6,7 & 5,2 \\
\hline 4 & Kandungan linoleat (\%) & 5,51 & 3,65 & 5,56 & 3,54 \\
\hline
\end{tabular}

Tabel 4 menunjukkan nilai maksimum dari parameter kuantitas dan kualitas minyak biji kapas pada masing-masing kluster atau grup. Pada parameter pengamatan jumlah biji.boll ${ }^{-1}$ adalah aksesi KANESIA-19, KANESIA-14, SA-2467, dan KANESIA-20 dengan nilai jumlah biji.boll ${ }^{-1} 22,5$ biji.boll ${ }^{-1}$, 22,1 biji.boll ${ }^{-1}$, 24,2 biji.boll ${ }^{-1}$, dan 25,6 biji.boll $^{-1}$. Parameter bobot biji.100 butir $^{-1}$ menunjukkan nilai pada masing-masing grup kluster yaitu 12 g, 11,25 g, 9 g, dan 11,25 g dengan aksesi CRIS-664, KANESIA-14, CRIS-668, dan KANESIA-13. Parameter kuantitas selanjutnya adalah hasil biji $\left(\mathrm{kg} \cdot \mathrm{ha}^{-1}\right)$ yang terdapat aksesi KANESIA-16, KANESIA-14, CRISS-670, dan KANESIA-17 dengan nilai pada masing-masing kluster adalah $641 \mathrm{~kg} \cdot \mathrm{ha}^{-1}, 413 \mathrm{~kg} \cdot \mathrm{ha}^{-1}, 222 \mathrm{~kg} \cdot \mathrm{ha}^{-1}$, dan $339 \mathrm{~kg} \cdot \mathrm{ha}^{-1}$. 
Pada parameter pengamatan kualitas yaitu kadar minyak dengan aksesi KANESIA-19, KANESIA-15, CRIS-666, dan CRIS-665 dengan nilai kadar minyak menunjukkan 16,6\%, 13,\%, 16,\%, dan 19,5\%pada masing-masing grup kluster. Parameter titik didih minyak terdapat aksesi CRIS-667, KANESIA-14, FDH-834, dan CRIS-665 menunjukkan nilai pada grup kluster adalah $67,4^{\circ} \mathrm{C}, 68,2^{\circ} \mathrm{C}, 70^{\circ} \mathrm{C}$ dan $67^{\circ} \mathrm{C}$. Parameter pengamatan kandungan oleat terdapat aksesi CRIS-667, CRIS-342, MARVI-425, dan CRIS-669 dengan nilai maksimum menunjukkan daei masing-masing grup kluster adalah 5,4\%,5,4\%, 6,7\%, dan 5,2\%. Parameter kuantitas pada kandungan linoleat menunjukkan nilai 5,51\%, 3,65\%, 5,56\% dan 3,54\% dengan aksesi SA-2465, KANESIA-15, SA2467, dan CRIS-665 pada masing-masing grup kluster.

Pada kelompok kluster pertama terdapat tujuh aksesi diantaranya Gossypium hirsutum dengan aksesi CRIS-664, CRIS-667, KANESIA-12, KANESIA-18, KANESIA-19 dan KANESIA-16. Gossypium barbadense dengan aksesi SA-2465, sedangkan pada grup pertama ditemukan adanya tingkat kekerabatan atau kemiripan pada genotip yang sama. Tingkat kemiripan tersebut terjadi di duga akibat level ploidi yang sama. Kapas dunia baru (Amerika) dengan jumlah kromosom tetraploid $(2 \mathrm{n}=4 \mathrm{x}=52$ kromosom). Diperkirakan merupakan persilangan alami antara kapas Dunia Lama dan Dunia Baru. Bentuk kromosomnya sebagian besar dan sebagian lagi kecil, mempunyai genom AD. Jenis kapas ini yang telah diketahui ada 6 spesies, dua diantaranya telah dibudidayakan, yaitu $G$. hirsutum (Amerika Tengah) dan G. barbadense (Amerika Selatan). Semakin tinggi kemiripan antar aksesi, semakin rendah pula tingkat keragaman genetik yang dihasilkan. Tingkat keragaman yang tinggi menghasilkan variasi genetik yang tinggi pula dalam program pemuliaan tanaman dengan hibridisasi.

Pada kelompok kluster kedua terdapat empat aksesi tersebut diantaranya Gossypium hirsutum dengan aksesi CRIS-342, KANESIA-14, KANESIA-15, dan KANESIA-11. Kemiripan sifat atau jarak genetik antar aksesi dapat digunakan sebagai indek seleksi tetua persilangan dan dapat dikembangkan untuk melakukan seleksi kombinasi tetua superior (Saparni, 2008). Pada kelompok kluster ketiga terdapat enam aksesi, aksesi tersebut diantaranya ialah spesies Gossypium barbadense dengan aksesi SA-2467, Gosyypium hirsutum dengan aksesi CRIS-666, CRIS,668, CRIS-670, dan pada spesies Gossypium arboreum dengan aksesi MARVI-425 dan FDH-834. Pada kelompok kluster keempat terdapat lima aksesi tersebut diantaranya spesies Gosspium hirsutum dengan aksesi CRIS665, CRIS-669, KANESIA-14, KANESIA-17, dan KANESIA-20.

\section{KESIMPULAN DAN SARAN}

\section{Kesimpulan}

Berdasarkan 22 aksesi plasma nutfah kapas yang digunakan terdapat keragaman genetik pada spesies Gossypium hirsutum dan terdapat adanya hubungan kekerabatan yang dekat antara spesies Gossypium hirsutum dan Gossypium barbadense. Hal ini mungkin disebabkan karena kedua spesies 
tersebut berasal dari sub genom yang sama. Nilai keragaman pada 22 aksesi plasma nutfah tersebut mempunyai angka range 12,35 dari 2,65 sampai dengan 15,00. Berdasarkan hasil seleksi terdapat calon tetua kapas yang terpilih yaitu spesies Gossypium hirsitum dengan aksesi CRISS-665, CRISS667, dan KANESIA-14 yang berkontribusi lebih unggul dari aksesi plasma nutfah kapas yang lainnya pada nilai maksimum parameter kuantitas dan kualitas minyak biji kapas.

\section{Saran}

Perlu dilakukan identifikasi karakter yang berkorelasi positif terhadap minyak biji kapas.

\section{DAFTAR PUSTAKA}

Amiroh, A. (2009). Pengaruh jarak tanaman kapas (Gossypium hirsutum) dan pemakaian jenis pupuk terhadap pertumbuhan dan produksi kapas berbiji pola tumpangsari kedelai (Glycium max). SAINTIS, 1(1), 29-36.

Ashokkumar, K., \& Ravikesavan, R. (2008). Genetic studies of combining ability estimates for seed oil, seed protein and fibre quality traits in upland cotton (G. hirsutum L.). Res. J. Agric. Biol. Sci, 4(6), 798-802.

Chalid, S. Y., Muawanah, A. \& Jubaedah, I. (2008). Analisa radikal bebas pada minyak goreng pedagang gorengan kaki lima. Jurnal Kimia VALENSI, 1(2), 82-86.

Direktorat Jenderal Perkebunan (2015). Laporan Kinerja Tahunan. Diambil kembali dari Kementerian Pertanian: http://ditjenbun. pertanian. go. id/files/LAPORAN_KINERJA_2013.pdf.

Kusuma, J., Ahsan, M. Z., Setiawan, W., Abdullah, K., \& Tahir, M. (2018). SSR-based diversity of domesticated and local cotton (Gossypium spp.) populations collected in Indonesia. International Journal of Agriculture and Biology, 20(9), 2019-2024.

Masyithah, Z., Sihombing, M. P., \& Tohang, L. V. B. Optimasi sintesis asam azelat dari asam oleat dan hidrogen peroksida menggunakan katalis asam tungstat. Jurnal Teknik Kimia USU, 6(3), 1421.

Moiana, L. D., Vidigal Filho, P. S., Gonçalves-Vidigal, M. C., \& de Carvalho, L. P. (2015). Genetic diversity and population structure of upland cotton Brazilian cultivars (Gossypium hirsutum L. raça latifolium H.) using SSR markers. Australian Journal of Crop Science 9(2), 143-152.

Nuraida, D. (2012). nalisis Variasi Genetik Varietas Unggul Kapas Gossypium hirsutum sebagai Materi Penyusun Buku Pengayaan Biologi. Disertasi, Program Studi Pendidikan Biologi. DISERTASI dan TESIS Program Pascasarjana UM.

Saeed, F., Farooq, J., Mahmood, A., Riaz, M., Hussain, T., \& Majeed, A. (2014). Assessment of genetic diversity for Cotton leaf curl virus (CLCuD), fiber quality and some morphological traits using different statistical procedures in'Gossypium hirsutum'L. Australian Journal of Crop Science, 8(3), 442.

Saparni, S. (2008). Identifikasi Sifat Morfologi Tanaman Jarak Pagar (Jatropha curcas L.) Aksesi Jawa di Kebun Induk Jarak Pagar Pakuwon. Unpublished undergraduate thesis, UNS, Surakarta. 
Tyagi, P., Gore, M. A., Bowman, D. T., Campbell, B. T., Udall, J. A., \& Kuraparthy, V. (2014). Genetic diversity and population structure in the US upland cotton (Gossypium hirsutum L.). Theoretical and Applied Genetics, 127(2), 283-295. 